\title{
Problematika Mahasiswa Bidikmisi Prodi Pendidikan Sejarah Angkatan 2013-2017
}

\author{
Niki Dwi Ayuningtyas ${ }^{1}$, Joko Sayono ${ }^{1}$, Endang Sri Andayani ${ }^{1}$ \\ ${ }^{1}$ Pendidikan Sejarah-Universitas Negeri Malang
}

\section{INFO ARTIKEL}

\section{Riwayat Artikel:}

Diterima: 10-03-2020

Disetujui: 20-08-2020

\section{Kata kunci: \\ bidikmisi students; history education; mahasiswa bidikmisi, pendidikan sejarah}

\author{
Alamat Korespondensi: \\ Niki Dwi Ayuningtyas \\ Pendidikan Sejarah \\ Universitas Negeri Malang \\ Jalan Semarang 5 Malang \\ E-mail: Nikidwi95@gmail.com
}

\begin{abstract}
ABSTRAK
Abstract: Probelamtika faced by Bidikmisi students is very diverse, factors that affect not only from themselves, but the external factors and the surrounding environment. This research focuses on describing the problems faced by Bidikmisi students during the study period. The method in this research uses descriptive qualitative case study approach. Data collection in this study uses observation, interviews and documentation. Subjects in this study were Bidikmisi students from 2013-2017. The results showed that each student has a different problem with other students in taking a period of study. For graduation, when compared to more Bidikmisi students who are not ontime.

Abstrak: Problematika yang dihadapi mahasiswa bidikmisi sangatlah beragam, faktor yang memengaruhi bukan hanya dari diri sendiri, melainkan faktor eksternal dan lingkungan sekitar. Penelitian ini berfokus untuk mendeskripsikan mengenai problematika yang dihadapi mahasiswa bidikmisi selama masa studi. Metode dalam penelitian ini menggunakan deskriptif kualitatif dengan pendekatan studi kasus. Pengumpulan data dalam penelitian ini menggunakan observasi, wawancara, dan dokumentasi. Subjek dalam penelitian ini adalah mahasiswa bidikmisi dari angkatan 2013-2017. Hasil penelitian menunjukkan bahwa setiap mahasiswa memiliki masalah yang berbeda dengan mahasiswa lainnya dalam menempuh masa studi. Untuk kelulusan, jika dibandingkan lebih banyak mahasiswa bidikmisi yang tidak tepat waktu.
\end{abstract}

Problematika yang dihadapi mahasiswa selama perkuliahan tidaklah hal yang asing lagi untuk didengar. Sebab setiap mahasiswa pasti memiliki masalah-masalah yang menghambat kuliahnya atau masa studi mereka. Menurut Winkel (2004) masalah atau problematika adalah suatu yang menghambat, merintangi, atau mempersulit seseorang dalam mencapai tujuan. Kondisi ini pastinya dapat mengganggu dan merugikan individu maupun lingkungannya. Problematika yang dihadapi mahasiswa biasanya bukan hanya dari diri sendiri, melainkan terdapat pula faktor dari luar dan lingkungan sekitar. Seperti yang dikemukakan oleh Giyono (2004) yang menyebutkan bahwa permasalahan yang dihadapi oleh mahasiswa, meliputi (1) kekhawatiran mengenai nilai ujian atau tugas, (2) kelemahan ketika memahami materi atau pekerjaan yang dikerjakan, (3) kurangnya percaya diri, (4) ceroboh, (5) kurang dapat mengatur keuangan, dan (6) kurang dapat mengontrol pergaulan. Dari hal tersebut maka dapat dibuktikan dengan banyaknya mahasiswa khususnya mahasiswa bidikmisi yang lulus tidak tepat waktu.

Mahasiswa bidikmisi pada dasarnya memiliki keistimewaan tersendiri, sebab mereka diberikan beasiswa dari pemerintah mulai semester awal hingga akhir (semester 1-8), namun banyak juga mahasiswa bidikmisi tingkat akhir mengalami keterlambatan kelulusan (Aprilia, Gusriani, \& Parmikanti, 2016). Beasiswa bidikmisi merupakan suatu program pendidikan dengan biaya dari pemerintah melalui Direktorat Jenderal Pendidikan Tinggi Kementerian Pendidikan dan Kebudayaan. Program ini mulai ada pada tahun 2010, dan program ini berlaku untuk mahasiswa yang memiliki prestasi akademik namun kurang mampu dalam perekonomiannya (Takriyuddin, Mukmin, \& Yunus, 2016). Mahasiswa bidikmisi biasanya dapat menyelesaikan pendidikannya dengan baik dan nilai di atas rata-rata teman sebayanya. Seperti pendapat Hamka dan Hartono (2012) beasiswa diperuntukkan bagi siswa yang berprestasi, namun kurang mampu dalam perekonomian untuk melanjutkan ke perguruan tinggi. Oleh karena itu, calon mahasiswa penerima bidikmisi merupakan siswa yang berprestasi di sekolahnya. Hal ini sependapat dengan Pengelolaan dan Penyelenggaraan Pendidikan, pada Pasal 53A yang menyatakan satuan pendidikan tinggi yang diselenggarakan Pemerintah Daerah dengan kewenangan masing-masing harus menyediakan beasiswa untuk mahasiswa yang berprestasi dan memiliki potensi akademik di atas rata-rata, namun kurang mampu dalam perekonomian, paling sedikit 20\% dari jumlah keseluruhan peserta didik baru (Panduan Bidikmisi, 2012). 
Calon mahasiswa bidikmisi sebelumnya juga telah melewati seleksi terlebih dahulu. Dengan adanya seleksi penerimaan mahasiswa bidikmisi, maka akan mengurangi peluang keterbukaan terjadinya kecurangan. Dimana banyak calon mahasiswa bidikmisi tidak bersyarat dapat memperoleh rekomendasi program studi tersebut (Ludfi \& Kumaidi, 1996). Hal ini merupakan tujuan pemerintah untuk menggambarkan nilai-nilai kehidupan. Karena pada dasarnya sebuah pendidikan harus memberikan arahan kepada kegiatan pendidikan dan juga keberhasilan yang akan dicapai pendidikan. Selain itu, tujuan pendidikan juga mengandung unsur norma yang sedikit bersifat memaksa, namun tidak bertentangan pada hakikat perkembangan peserta didik dan dapat diterima oleh masyarakat (Tirarahardja \& La Sulo, 2003).

Beasiswa bidikmisi diperuntukkan bagi mahasiswa yang kurang mampu (Kharismayanti, 2017). Beasiswa bidikmisi yang diberikan kepada mahasiswa oleh pemerintah berupa fasilitas khusus, meliputi (1) pembebasan biaya pendaftaran seleksi masuk perguruan tinggi, (2) penggantian biaya kedatangan pertama untuk pendaftar Bidikmisi, (3) pembebasan biaya pendidikan, dan (4) subsidi biaya hidup sebesar Rp 650.000,00 per bulan (Kemenristekdikti, 2019). Dengan diberikan keistimewaan tersebut, maka diharapkan dapat menggunakan dengan sebaik-baiknya. Namun, dalam realitanya banyak mahasiswa bidikmisi yang tidak bisa menyelesaikan masa studinya dengan tepat waktu. Hal ini diperkuat dengan pendapat dari Al Amin (2013) yang menyatakan bahwa dalam praktiknya, mahasiswa tidak selalu dapat menyelesaikan masa studinya dalam waktu empat tahun. Sama halnya dengan pendapat Ihsan dan Zaki (2015) bisa lulus tepat waktu sudah barang tentu jadi keinginan untuk setiap mahasiswa. Biasanya, untuk mahasiswa S1 masa studinya sekitar 4 -5 tahun. Seharusnya dari pihak universitas mendeteksi terlebih dahulu mengenai permasalahan yang dihadapi mahasiswanya sehingga tidak terlambat untuk lulusan. Dalam mengatasi permasalahan ini, perlu adanya pendalaman agar bisa melakukan prediksi terhadap kelulusan mahasiswa tersebut (Rohmawan, 2018). Dengan demikian, jika dibuat perbandingan, maka akan terlihat jelas bahwa lebih banyak mahasiswa bidikmisi yang lulus dari kurun waktu empat tahun.

\section{METODE}

Metode yang digunakan untuk penelitian ini merupakan metode deskriptif kualitatif dengan pendekatan studi kasus (case study). Penelitian kualitatif ini lebih menjaga fokusnya dengan cara mempelajari pemaknaan dari para partisipan terhadap permasalahan (Creswell, 2014). Penelitian ini berpusat pada suatu objek dengan mempelajari sebuah kasus. Studi kasus deskriptif ini bertujuan agar dapat melacak peristiwa yang menghubungkan antar pribadi, menggambarkan subbudaya yang dapat dikatakan jarang dijadikan topik penelitian, serta memiliki kemampuan fenomena kunci seperti kemajuan karier para pemuda untuk mengesampingkan ikatan lingkungan (Yin, 2002). Teknik analisis data penelitian ini diperoleh dari berbagai sumber dan menggunakan pengumpulan dengan mengolahnya hingga valid (Etika \& Hasibuan, 2016). Alasan penelitian ini memilih jenis penelitian studi kasus karena dianggap lebih cocok. Secara garis besar, studi kasus adalah strategi suatu peneliti dangan "how" atau "why", dan peneliti memiliki peluang kecil dalam mengontrol peristiwa yang diteliti, serta dalam fokus penelitiannya terletak di fenomena sekarang dengan konteks pada kehidupan nyata (Yin, 2002). Studi kasus merupakan suatu metode gabungkan dari mengumpulkan data wawancara, angket, dan observasi awal. Serta terdapat paling sedikit empat problem yang harus difokuskan, yaitu mengenai pertanyaan yang diajukan, data yang sinkron, data yang dikumpulkan dan cara analisis hasilnya (Philiber, dkk, 1980). Dengan demikian, peneliti memilih untuk menggunakan penelitian deskriptif kualitatif dengan pendekatan studi kasus agar mempermudah mendalami masalah atau problematika yang dihadapi oleh mahasiswa bidikmisi dalam menempuh masa studi. Subjek penelitian ini adalah mahasiswa bidikmisi prodi S1 pendidikan sejarah angkatan 2013-2017. Jumlah mahasiswa yang diwawancarai oleh peneliti berjumlah 52 mahasiswa bidik misi dari berbagai angkatan dan berbagai masalah yang dihadapinya.

\section{HASIL}

Hasil dari penelitian ini dibagi menjadi empat kategori. Adapun temuan yang akan dikemukakan oleh peneliti sebagaimana ditunjukkan pada tabel 1-4. Tabel 1 mahasiswa bidikmisi yang belum lulus dengan ada masalah. Tabel 2 mahasiswa bidikmisi yang belum lulus dengan tidak ada masalah. Tabel 3 mahasiswa bidikmisi yang sudah lulus dengan ada masalah. Tabel 4 mahasiswa bidikmisi yang sudah lulus dengan tidak ada masalah. dari keempat kategori tersebut. Selain itu, peneliti juga menggunakan Indeks Prestasi (IP) untuk mahasiswa bidikmisi yang belum lulus dan Indeks Prestasi Kumulatif (IPK) untuk mahasiswa bidikmisi yang sudah lulus.

Tabel 1. Mahasiswa Bidikmisi yang Belum Lulus Dengan Ada Masalah

\begin{tabular}{lccl}
\hline \multicolumn{1}{c}{ Nama } & Angkatan & Indeks Prestasi (IP) & \multicolumn{1}{c}{ Permasalahan yang Dihadapi } \\
\hline Irmaya Merdiana & 2015 & 3,49 & Revisi setelah sidang hampir dua bulan baru diberikan ke mahasiswa \\
\hline Siti Faizatun Nisa' & 2015 & 3,80 & $\begin{array}{l}\text { Hubungan dengan tempat penelitian yang sulit } \\
\text { Sumber berbahasa asing } \\
\text { Revisi setelah sidang yang cukup lama (23 Mei-20 Agustus) }\end{array}$ \\
\hline Leni Sagita & 2015 & 3,77 & $\begin{array}{l}\text { Kesulitan dalam materi } \\
\text { Revisi setelah sidang lebih dari satu bulan }\end{array}$ \\
\hline Iqbal Alkautsar & 2015 & 3,55 & $\begin{array}{l}\text { Administrasi di fakultas yang membutuhkan waktu yang lama } \\
\text { Setelah sidang, materi dan media harus banyak diubah }\end{array}$ \\
\hline
\end{tabular}


Tabel 1. Mahasiswa Bidikmisi yang Belum Lulus Dengan Ada Masalah (Lanjutan)

\begin{tabular}{lccl}
\hline \multicolumn{1}{c}{ Nama } & Angkatan & Indeks Prestasi (IP) & \multicolumn{1}{c}{ Permasalahan yang Dihadapi } \\
\hline Tri Ambarninrum & $\mathbf{2 0 1 5}$ & $\mathbf{3 , 7 0}$ & $\begin{array}{l}\text { Judul skripsi diubah setelah seminar proposal } \\
\text { Bergantinya tempat penelitian yang cukup jauh dari rumah }\end{array}$ \\
$\begin{array}{l}\text { Yunis Roisatul } \\
\text { Mageknifah }\end{array}$ & 2015 & 3,47 & $\begin{array}{l}\text { Revisi setalah sidang lebih dari satu bulan } \\
\text { Karena revisi lama, menjadi malas ke kampus }\end{array}$ \\
\hline $\begin{array}{l}\text { Muhammad Ali Zainal } \\
\text { Abidin }\end{array}$ & 2014 & 3,28 & $\begin{array}{l}\text { Kerja } \\
\text { Malas ke kampus } \\
\text { satu tahun tidak melakukan bimbingan }\end{array}$ \\
\hline Dyan Dianggra & 2013 & $\begin{array}{l}\text { Malas } \\
\text { Cuti satu tahun dan baru mulai mengerjakan skripsi lagi di semester 13 }\end{array}$ \\
\hline Teti Ermawati & 2015 & 3,04 & $\begin{array}{l}\text { Revisi dari dosen sangat lama setelah sidang (Juli- September) } \\
\text { Penelitian tertunda karena seolah melaksanakan ujian nasional }\end{array}$ \\
\hline Eka Nosa Ramadani & 2015 & 3,61 & $\begin{array}{l}\text { Perizinan di sekolah sangat susah } \\
\text { Sekolah menunda mahasiswa melakukan penelitian karena pihak sekolah } \\
\text { sedang melaksanakan ujian nasional }\end{array}$ \\
\hline Siti Musrifah & 2015 & 3,36 & Administrasi di fakultas cukup lama \\
\hline
\end{tabular}

Tabel 2. Mahasiswa Bidikmisi yang Belum Lulus Dengan Tidak Ada Masalah

\begin{tabular}{|c|c|c|c|}
\hline Nama & Angkatan & Indeks Prestasi (IP) & Permasalahan yang Dihadapi \\
\hline Rica Filasari & 2016 & 3,75 & $\begin{array}{l}\text { Baru memulai bimbingan skripsi } \\
\text { Kesulitan mengakses jurnal untuk tugas kuliah }\end{array}$ \\
\hline Intan Choni Kustantia & 2016 & 3,16 & $\begin{array}{l}\text { Memulai bimbingan skripsi } \\
\text { satu matakuliah pernah tidak lulus }\end{array}$ \\
\hline Moh. Nazri Aldani & 2016 & 3,59 & $\begin{array}{l}\text { Baru memulai bimbingan skripsi } \\
\text { Sudah mulai terlihat kesulitan membuat materi dan media untuk penelitian }\end{array}$ \\
\hline Tinto Pratama & 2016 & 3,45 & $\begin{array}{l}\text { Baru memulai bimbingan skripsi } \\
\text { Kesulitan ketika tugas dari dosen mengharuskan penelitian di luar kampus }\end{array}$ \\
\hline Dinda Prima Ananda & 2016 & 3,56 & $\begin{array}{l}\text { Baru mulai bimbingan skripsi } \\
\text { Tugas berjalan lancar }\end{array}$ \\
\hline Grahandy Yulia Fadlika & 2016 & 3,25 & $\begin{array}{l}\text { Baru memulai bimbingan skripsi } \\
\text { Mulai terlihat kesulitan untuk membuat media dan sumbernya }\end{array}$ \\
\hline Muhammad Nur Faizin & 2016 & 3,15 & $\begin{array}{l}\text { Adaptasi di awal kuliah } \\
\text { Belum memulai bimbingan } \\
\text { Kesulitan menemui dosen untuk bimbingan }\end{array}$ \\
\hline Sananil Huda & 2016 & 3,44 & $\begin{array}{l}\text { Belum memulai bimbingan } \\
\text { Bingung mau membuat media dan materi apa }\end{array}$ \\
\hline Agung Nasrullah & 2016 & 3,44 & Baru memulai bimbingan \\
\hline Chusnul Muzdalifah & 2016 & 3,50 & $\begin{array}{l}\text { Awal kuliah tidak ada laptop } \\
\text { Baru memulai bimbingan } \\
\text { Kesulitan menemui dosen }\end{array}$ \\
\hline Anita Syahru Romadhona & 2016 & 3,62 & $\begin{array}{l}\text { Baru akan bimbingan skripsi setelah KPL berakhir } \\
\text { Mengkaji sejarah lokal sehingga sulit menemukan sumber }\end{array}$ \\
\hline Alifah Fitriana R. & 2016 & 3,58 & $\begin{array}{l}\text { Baru memulai bimbingan skripsi } \\
\text { Sumber data yang susah didapatkan }\end{array}$ \\
\hline Hesty Ika Sukma Shakti & 2016 & 3,77 & $\begin{array}{l}\text { Baru memulai bimbingan skripsi } \\
\text { Kesulitan dalam sumber penelitian dan media }\end{array}$ \\
\hline Song Song Wicaksono & 1017 & 3,64 & Permasalahan ekonomi \\
\hline Aditiya Septiyanto & 2017 & 3,47 & $\begin{array}{l}\text { Tempat tinggal di Malang kurang nyaman } \\
\text { Sering kurang paham terkait materi yang diajarkan }\end{array}$ \\
\hline Cici Widariyanti & 2017 & 3,84 & $\begin{array}{l}\text { Kurang bisa memanejemen waktu } \\
\text { Banyak tugas setiap minggunya }\end{array}$ \\
\hline Hilda Erianti & 2017 & 3,53 & Dalam mengerjakan tugas tidak ada masalah \\
\hline Ayisatun Nasri’ah & 2017 & 3,43 & Kesulitan mengakses jurnal \\
\hline Zulfa Inayatul Aini & 2017 & 3,86 & Kendala ada tugas kelompok, selalu terbebani yang paling banyak \\
\hline Rizki Fikri F & 2017 & 3,41 & $\begin{array}{l}\text { Masalah ekonomi } \\
\text { Kendala masih batas wajar }\end{array}$ \\
\hline Nerry Supanji & 2017 & 3,72 & $\begin{array}{l}\text { Masalah ekonomi } \\
\text { Sifat malas yang sulit hilang }\end{array}$ \\
\hline
\end{tabular}


Tabel 3. Mahasiswa Bidikmisi yang Sudah Lulus Dengan Ada Masalah

\begin{tabular}{|c|c|c|c|c|}
\hline Nama & Angkatan & Indeks Prestasi Kumulatif & Kelulusan Mahasiswa & Permasalahan yang Dihadapi \\
\hline Ayu Hardiayanti & 2014 & 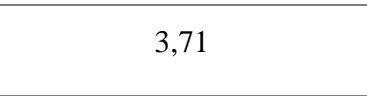 & $\begin{array}{l}4 \text { tahun dan semester } \\
\text { pendek (SP) }\end{array}$ & $\begin{array}{l}\text { Sumber susah diakses } \\
\text { Biaya membuat media yang cukup mahal }\end{array}$ \\
\hline Ainun Hidayah & 2014 & 3,55 & $\begin{array}{l}4 \text { tahun dan semester } \\
\text { pendek (SP) }\end{array}$ & $\begin{array}{l}\text { Sumber pendukung materi sulit } \\
\text { Kerja sambil kuliah }\end{array}$ \\
\hline Ika Indana Zulfa & 2015 & 3,57 & 4 tahun & $\begin{array}{l}\text { Kesulitan membuat media dan materi untuk } \\
\text { penelitian } \\
\text { Metode penelitian berubah }\end{array}$ \\
\hline Moch. Sadewa & 2014 & 3,49 & 4,5 tahun & $\begin{array}{l}\text { Penelitian memakan waktu urang lebih 2,5 } \\
\text { bulan (sekolah ada kegiatan) } \\
\text { Revisi setelah sidang sedikit lama }\end{array}$ \\
\hline $\begin{array}{l}\text { Kyky Miftakhul } \\
\text { Jannah }\end{array}$ & 2013 & 3,23 & $\begin{array}{l}4 \text { tahun dan semester } \\
\text { pendek (SP) }\end{array}$ & $\begin{array}{l}\text { Kurang faham jenis penelitian (metode diubah } \\
\text { dari kualitatif ke PTK) }\end{array}$ \\
\hline $\begin{array}{l}\text { Jaylani Abdul } \\
\text { Azis }\end{array}$ & 2013 & 3,07 & 5 tahun & $\begin{array}{l}\text { Administrasi di tempat penelitian membuat } \\
\text { kesulitan }\end{array}$ \\
\hline $\begin{array}{l}\text { Masayu } \\
\text { Permatahati }\end{array}$ & 2013 & 3,26 & $\begin{array}{l}4 \text { tahun dan semester } \\
\text { pendek (SP) }\end{array}$ & $\begin{array}{l}\text { Kesulitan dalam pembuatan media dan materi, } \\
\text { serta membutuhkan waktu yang cukup lama } \\
\text { Kekurangan sumber untuk materi }\end{array}$ \\
\hline Dedi Darmadi & 2014 & 3,52 & $\begin{array}{l}4 \text { tahun dan semester } \\
\text { pendek (SP) }\end{array}$ & $\begin{array}{l}\text { Kesulitan dalam mengolah sumber (baik teks } \\
\text { dan narasumber) }\end{array}$ \\
\hline Indah Dwi Lestari & 2013 & 3,39 & 4,5 tahun & $\begin{array}{l}\text { Dua kali ganti judul dan metode (dari } \\
\text { kualitatif ke kuantitatif) } \\
\text { Membutuhkan waktu untuk belajar SPSS }\end{array}$ \\
\hline Rikha Lilafatu R & 2013 & 3,05 & 4,5 tahun & $\begin{array}{l}\text { Kesulitan dalam membuat media } \\
\text { Tempat penelitian jauh }\end{array}$ \\
\hline $\begin{array}{l}\text { Mei Linda Ayu } \\
\text { W. }\end{array}$ & 2014 & 3,44 & $\begin{array}{l}4 \text { tahun dan semester } \\
\text { pendek (SP) }\end{array}$ & $\begin{array}{l}\text { Rnd membutuhkan waktu yang lama } \\
\text { Lokasi penelitian yang jauh } \\
\text { Revisi media dan materi yang cukup lama }\end{array}$ \\
\hline Setia Ningrum & 2014 & 3,64 & $\begin{array}{l}4 \text { tahun dan semester } \\
\text { pendek (SP) }\end{array}$ & $\begin{array}{l}\text { Sifat malas keluar } \\
\text { Kurang telaten dalam mengerjakan } \\
\text { Dosen sulit ditemui }\end{array}$ \\
\hline Nailul Faudhoh & 2015 & 3,53 & 4,5 tahun & $\begin{array}{l}\text { Menemui guru di tempat penelitian sangat } \\
\text { sulit }\end{array}$ \\
\hline
\end{tabular}

Tabel 4. Mahasiswa Bidikmisi yang Sudah Lulus Dengan Tidak Ada Masalah

\begin{tabular}{lcccl}
\hline \multicolumn{1}{c}{ Nama } & Angkatan & Indeks Prestasi Kumulatif & Kelulusan Mahasiswa & \multicolumn{1}{c}{ Argumen Mahasiswa } \\
\hline $\begin{array}{l}\text { Muhammad Yusuf } \\
\text { Efendi }\end{array}$ & 2015 & 3,61 & 3,5 tahun & $\begin{array}{l}\text { Lulus } 7 \text { semester } \\
\text { Tidak ada kendala } \\
\text { Ikut serta dengan penelitian dosen }\end{array}$ \\
\hline Miftakhul Khassanah & 2013 & 3,81 & 4 tahun & $\begin{array}{l}\text { Lulus tepat waktu } \\
\text { Kuliah dan bekerja (mengajar di } \\
\text { bimbingan belajar) }\end{array}$ \\
\hline Yeni Eria Ningsih & 2013 & 3,55 & 4 tahun & $\begin{array}{l}\text { Lulus tepat waktu } \\
\text { Media dan materi lancar dalam } \\
\text { mengerjakan }\end{array}$ \\
\hline Rokhimatul Jannah & 2013 & 3,52 & 4 tahun & $\begin{array}{l}\text { Berganti-ganti judul tidak menghambat } \\
\text { untuk lulus tepat waktu }\end{array}$ \\
\hline Danan Tricahyono & 2013 & 3,73 & 4 tahun & $\begin{array}{l}\text { Lulus tepat waktu } \\
\text { Skripsi pertama yang membahas cara } \\
\text { berpikir historis }\end{array}$ \\
\hline Imam Ropi'i & 2013 & 3,54 & $\begin{array}{l}\text { Bekerja tidak menghambat untuk tetap } \\
\text { bisa lulus tepat waktu }\end{array}$ \\
\hline Erni Widyawati & 2013 & 3.21 & $\begin{array}{l}\text { Lulus tepat waktu } \\
\text { Studi lancar }\end{array}$ \\
\hline
\end{tabular}




\section{PEMBAHASAN}

\section{Mahasiswa Bidikmisi yang Belum Lulus dengan Ada Masalah}

Berdasarkan hasil penelitian yang dilakukan pada kategori ini, terdapat 11 mahasiswa bidikmisi yang belum lulus dengan ada masalah. Permasalahan yang dialami mahasiswa bidikmisi pada kategori ini adalah revisi yang cukup lama, kerja, malas datang ke kampus, sulitnya mengakses sumber, administrasi fakultas yang cukup lama. Hal ini diperkuat dengan pendapat Raharjo (2014) masalah yang dihadapi oleh mahasiswa semester tua adalah masalah akademik dan non akademik. Hal ini dapat disimpulkan, bahwa ekspektasi dari pemerintah tidak selalu sejalan dengan kenyataan. Sebab masih banyak kendala yang menyebabkan mahasiswa bidikmisi tidak dapat menyelesaikan studinya dengan baik dan maksimal. Menurut Siang (2009) keterlambatan menyelesaikan masa studi terdapat dua faktor, yaitu (1) faktor internal yang meliputi minat rendah, motivasi dari diri sendiri dan akademik yang rendah. (2) faktor eksternal yang meliputi sulitnya ide untuk mengerjakan skripsi, sulitnya literatur dan permasalahan yang ada pada dosen pembimbing. Padahal seharusnya jenjang S1 dapat ditempuh dalam waktu cukup singkat. Menurut peraturan akademik, jenjang S1 dapat ditempuh dalam kurun waktu empat tahun dan untuk jenjang D3 dapat ditempuh dalam waktu tiga tahun (Widarto, 2017).

Peneliti juga memperkuat temuan dengan menggunakan Indeks Prestasi (IP). Dalam katagori ini, mahasiswa bidikmisi yang mendapatkan Indeks Prestasi (IP) cumlaude sebanyak enam mahasiswa dan lima mahasiswa yang mendapatkan Indeks Prestasi (IP) dengan memuaskan. Mahasiswa bidikmisi tidak semuanya bisa mendapatkan Indeks Prestasi (IP) sesuai dengan standart yang telah ditentukan (Arsana, 2006). Hasil belajar atau lebih dikenal dengan Indeks Prestasi (IP) dan Indeks Prestasi Kumulatif (IPK) pada dunia perkuliahan, adalah kemampuan dari mahasiswa setelah selesai mengikuti proses belajar, dan bisa mengubah perilaku, pengetahuan, pemahaman, sikap, dan keterampilan mahasiswa menjadi lebih baik (Purwanto, 2002). Dengan demikian, dapat disimpulkan bahwa mahasiswa bidikmisi dalam kategori ini memiliki kendala yang berbeda antar mahasiswa lainnya. Kendala yang dihadapi mahasiswa dalam katagori ini bukan perkara mendapatkan Indeks Prestasi (IP), melainkan mengenai penyelesaian masa studi (mengerjakan skripsi) dan proses mengerjakannya. Khususnya bagi mahasiswa yang sudah sidang skripsi dan hasil revisi cukup lama. Untuk Indeks Prestasi (IP) dalam kategori ini lebih banyak yang cumlaude. Pencapaian Indeks Prestasi (IP) yang diperoleh mahasiswa bidikmisi bergantung pada kemampuan individu tersebut.

\section{Mahasiswa Bidikmisi yang Belum Lulus dengan Tidak Ada Masalah}

Berdasarkan hasil penelitian, pada kategori ini mahasiswa yang diwawancarai pada kategori ini adalah mahasiswa angkatan 2016 dan 2017 yang baru mulai bimbingan skripsi dan masih menempuh matakuliah. Problematika yang dihadapi mahasiswa bidikmisi angkatan 2016, yaitu kesulitan menemui dosen untuk bimbingan, kesulitan membuat media dan materi untuk skripsi, dan kesulitan untuk mengakses jurnal, sedangkan problematika mahasiswa bidikmisi angkatan 2017 adalah masalah ekonomi, kesulitan mengakses jurnal, dan sifat malas. Permasalahan yang dihadapi mahasiswa bidikmisi kategori ini sangatlah berbeda. Sebab dari angkatan 2016 sudah memulai bimbingan skripsi dan angkatan 2017 baru mulai belajar membuat proposal pada matakuliah metodologi penelitian. Jadi, permasalahan pada kategori ini masih dapat dikatakan permasalahan yang wajar dihadapi mahasiswa pada umumnya. Sama halnya dengan pernyataan Sugiarto (2002) terdapat beberapa permasalahan yang dihadapi mahasiswa, antara lain (1) penyesuaian lingkungan, (2) stress ketika ujian, (3) malas, (4) ketidakmampuan belajar dengan baik, (5) kehilangan teman, (6) pernah mengalami kegagalan, (7) peraturan sekolah yang dirasa memberatkan, (8) tekanan dan ambisi orangtua, dan (9) hubungan antara mahasiswa dengan dosen dan teman sebaya. Agar dapat lulus dari sebuah universitas, maka mahasiswa harus menyelesaikan beban untuk mengerjakan skripsi dan tugastugas yang ada pada semester sebelumnya (Amira, 2016).

Peneliti juga memperkuat hasil penelitian dengan menggunakan Indeks Prestasi (IP). Secara umum, menurut Abdurrahman (2009) hasil belajar atau lebih dikenal Indeks Prestasi (IP) atau Indeks Prestasi Kumulatif (IPK) untuk jenjang perkuliahan, merupakan sebuah kemampuan yang didapatkan mahasiswa menyelesaikan kegiatan belajar. Mahasiswamahasiswa yang berhasil dalam belajar merupakan capaian dari tujuan instruksional. Pada kategori ini, dari total 21 mahasiswa dari angkatan 2016 dan 2017 diantaranya 13 mahasiswa dari angkatan 2016 dan delapan dari angkatan 2017. Pada angkatan 2016, enam dari 13 mahasiswa merupakan mahasiswa yang mendapatkan Indeks Prestasi cumlaude. Angkatan 2017 jumlah mahasiswa sebagai subjek penelitian berjumlah delapan mahasiswa, lima dari delapan mahasiswa ini mendapatkan Indeks Prestasi (IP) cumlaude. Jika dijumlahkan, pada kategori ini terdapat 11 mahasiswa yang mendapatkan Indeks Prestasi (IP) cumlaude. Kesimpulan dari kategori ini ialah setiap mahasiswa memiliki permasalahan yang berbeda, terutama pembeda angkatan 2016 dan 2017. Kendala yang dihadapi mahasiswa dalam katagori ini bukan perkara mendapatkan Indeks Prestasi (IP), melainkan mengenai penyelesaian proses awal bimbingan, mengakses sumber untuk penelitian bagi angkatan 2016. Sementara itu, permasalahan untuk angkatan 2017 lebih mengarah pada masalah ekonomi dan menyelesaikan tugas kelompok atupun individu.

\section{Mahasiswa Bidikmisi yang Sudah Lulus dengan Ada Masalah}

Berdasarkan hasil penelitian, pada kategori ini terdapat 13 mahasiswa yang sudah lulus dengan ada masalah. Permasalahan yang dihadapi oleh mahasiswa dalam kategori ini adalah proses pembuatan media untuk skripsi yang memakan waktu, kesulitan membuat media dan materi, pengolahan data setelah penelitian, dan sifat malas. Tidak dapat dipungkiri bahwa 
setiap mahasiswa dalam proses belajar dan mengerjakan skripsi menjumpai banyak masalah (Fachrurrozie dkk, 2018). Masalahmasalah mahasiswa akan terlihat ketika sudah menjelang semester akhir (Samekto, Syafrudie, Sutrisno, 2014). Masalah yang signifikan bagi mahasiswa untuk mempelajari dan menyelesaikan tugas akhir merupakan pola yang harus dilewati, agar mereka dapat menghadapi permasalahan mendatang (Albashtawi, 2014). Peneliti mewawancarai mahasiswa bidikmisi dari angkatan 2013, 2014, dan 2015 pada kategori ini. Indeks Prestasi Kumulatif (IPK) mahasiswa bidikmisi kategori ini sudah diklasifikasikan peneliti, yaitu enam mahasiswa mendapatkan Indeks Prestasi Kumulatif (IPK) dengan pujian atau cumlaude dan tujuh mahasiswa mendapatkan Indeks Prestasi Kumulatif (IPK) dengan memuaskan. Dari jumlah keseluruhan mahasiswa bidikmisi dalam katagori ini, peneliti mewawancarai lima mahasiswa angkatan 2013, enam mahasiswa angkatan 2014, dan dua mahasiswa angkatan 2015.

Menurut Sudjana \& Rivai (2001) terdapat beberapa faktor yang memengaruhi hasil belajar atau lebih dikenal dengan Indeks Prestasi Kumulatif (IPK), salah satunya jasmani dan rohani siswa. Hal ini berkaitan dengan kesehatan fisik mahasiswa secara umum, sedangkan faktor lingkungan juga berpengaruh. Hasil belajar seorang mahasiswa di kampus $70 \%$ dipengaruhi oleh kemampuan siswa dan 30\% dipengaruhi oleh lingkungan. Dengan pengaruh lingkungan, menjadikan mahasiswa kurang termotivasi dan bahkan beralasan tidak ada waktu untuk mengerjakan tugas dari dosen (Rahmiati, 2014). Kesimpulan yang didapatkan dalam kategori ini adalah kendala yang dihadapi mahasiswa dalam katagori ini juga merupakan perkara untuk mendapatkan Indeks Prestasi Kumulatif (IPK) yang masih pada batas sangat memuaskan. Bahkan, untuk masa studi, kebanyakan mahasiswa bidikmisi pada kategori ini tidak lulus tepat waktu hanya terdapat satu mahasiswa yang lulus di semester delapan. Untuk kelulusan pada semester delapan dengan semester pendek (SP) terdapat tujuh mahasiswa, untuk kelulusan pada semester sembilan terdapat empat mahasiswa, dan untuk yang lulus di semester 10 terdapat satu mahasiswa.

\section{Mahasiswa Bidikmisi yang Lulus dengan Tidak Ada Masalah}

Berdasarkan hasil penelitian, pada kategori ini terdapat tujuh mahasiswa yang lulus dengan tidak ada masalah. Walaupun banyak yang mengikuti kegiatan lain selain kuliah tapi pada kategori ini tetap bisa memberikan hasil yang maksimal. Dalam kategori ini dapat disimpulkan, bahwa ekspektasi dari pemerintah sejalan dengan kenyataan. Sebab dari diri mahasiswa bidikmisi untuk kategori ini, mereka tetap fokus dan optimis untuk bisa menyelesaikan masa studi dengan hasil yang benarbenar memuaskan. Karena mahasiswa yang memiliki minat belajar tinggi akan memberikan perhatian penuh dengan usahanya agar mencapai tujuan tertentu (Aslinawati \& Mintarti, 2017). Dengan minat tinggi maka proses bimbingan mahasiswa dan dilanjutkan dengan seminar proposal yang dihadiri oleh dosen penanggap akan membantu memberikan masukan demi kesempurnaan proposal yang ditulis (Rismen, 2015). Mahasiswa bidikmisi pada kategori ini juga memiliki strategi pembelajaran yang disiplin untuk mengantisipasi permasalahan yang tidak terduga (Saparwadi \& Aini, 2016). Peneliti juga menggunakan Indeks Prestasi Kumulatif (IPK). Dalam katagori ini, peneliti mewawancarai mahasiswa bidikmisi dari angkatan 2013 dan 2015. Untuk mahasiswa angkatan 2013 terdapat enam mahasiswa bidikmisi dan untuk angkatan 2015 hanya terdapat satu mahasiswa bidikmisi. Dari jumlah keseluruhan hanya ada satu mahasiswa yang Indeks Prestasi Kumulatif (IPK) tidak cumlaude. Mahasiswa yang menerima beasiswa bidikmisi memiliki semangat belajar lebih tinggi sehingga mendapatkan prestasi yang baik (Afida, dkk, 2018).

Keberhasilan mendapatkan predikat cumlaude pastinya ada rasa puas tersendiri dari dalam diri mahasiswa. Menurut Dimyati dan Mudjiono (2006) hasil belajar adalah suatu proses untuk mengetahui kemampuan siswa dalam menguasai pembelajaran setelah proses mengajar selesai, dan keberhasilannya ditandai dengan bentuk angka, huruf, atau simbol tertentu yang disepakati oleh pihak penyelenggara pendidikan. Hasil belajar merupakan tingkat penguasaan yang dicapai oleh siswa dalam program belajar mengajar. Hasil belajar adalah sebuah indikator dari proses belajar yang mengubah perilaku siswa setelah mengikuti aktivitas belajar (Anni, 2004). Setelah kelulusan dicapai, maka mahasiswa bidikmisi tersebut akan berlanjut pada wisuda. Sebab pada dasarnya, setiap perguruan tinggi diharapkan menghasilkan lulusan yang berkompeten (Sumartini \& Disman, 2018). Kesimpulan dari kategori ini ialah hampir semua mahasiswa bidikmisi dapat mencapai Indeks Prestasi Kumulatif (IPK) cumlaude dan lulus tepat waktu, bahkan ada yang lulus di semester tujuh. Walaupun setiap mahasiswa memiliki cara yang berbeda dalam menyelesaikan masa studi, tetapi jika memiliki kemauan yang tinggi serta usaha yang sungguh-sungguh, maka mereka dapat melalui kendala yang berkaitan dengan masa studi.

\section{SIMPULAN}

Berdasarkan hasil penelitian menunjukkan bahwa setiap mahasiswa memiliki masalah yang berbeda dengan mahasiswa lainnya dalam menempuh masa studi. Untuk kelulusan, jika dibandingkan lebih banyak mahasiswa bidikmisi yang lulus tidak tepat waktu. Sebab kesalahan mahasiswa tidak lulus tepat waktu bukanlah semata-mata karena kesalahan mahasiswa itu sendiri, karena dosen dan tempat penelitian juga memengaruhi hasil akhir mahasiswa dapat lulus tepat waktu atau tidaknya. Penelitian ini disarankan kepada Universitas Negeri Malang agar bisa digunakan untuk menambah referensi dan untuk pertimbangan jika terdapat permasalahan yang sama dengan penelitian ini. Serta diharapkan dapat digunakan untuk acuan penelitian selanjutnya. 


\section{DAFTAR RUJUKAN}

Abdurrahman, M. (2009). Pendidikan bagi Anak Berkesulitan Belajar. Jakarta: Rineka Cipta.

Afida, Z. N. (2011). Pengaruh Beasiswa Bidikmisi dan Kemandirian Belajar terhadao Prestasi Belajar Mahasiswa Bidikmisi Tahun Angkatan 2014 Fakultas Keguruan dan Ilmu Pendidikan Universitas Sebelas Maret Surakarta. Jurnal Pendidikan Bisnis dan Ekonomi, 4(2).

Al Amin, F. N., Indahwati., \& Angraini, Y. (2013). Analisis Ketepatan Waktu Lulus Berdasarkan Karakteristik Mahasiswa Fem dan Faperta menggunakan Metode Chart. Xplore: Journal of Statistics, 2(1), 1-8.

Albashtawi, A. H. (2014). Student's Perspectives for the Encountered Problems \& Challenges at the Department of English in The Colege of Sciences \& Arts In Alqurrayyat. International Journal of Education and Research, 2(2), 1-8.

Amira, N. (2006). Faktor-Faktor Yang Memengaruhi Terlambatnya Penyelesaian Studi pada Mahasiswa Fakultas Ilmu Sosial dan Ilmu Politik Universitas Riau. Jurnal FISIP, 3(2), 1-14.

Aprilia K, T., Gusriani, N., \& Parmikanti, K. (2016). Klasifikasi Ketepatan Masa Studi Mahasiswa FMIPA Unpad Angkatan 2001-2006 dengan Menggunakan Metode Classification and Regression Trees (CART). Jurnal Matematika Integratif, 11(1), 7-14. https://doi.org/10.24198/jmi.v11.n1.7944.7-14

Arsana, I. W. B. (2016). Kecenderungan Prestasi Belajar Mahasiswa Penerima Beasiswa Bidikmisi di Fakultas Ekonomi dan Bisnis Universitas Pendidikan Ganesha Angkatan 2010. Jurnal Program Studi Pendidikan Ekonomi, 6(1), 1-10.

Aslinawati, E. N., \& Mintarti, W. S. U. (2017). Keterlambatan Penyelesaian Skripsi Mahasiswa Angkatan 2012 (Studi Kasus di Jurusan Ekonomi Pembangunan Fakultas Ekonomi Universitas Negeri Malang. Jurnal Pendidikan Ekonomi, 10(1), $23-33$. DOI: https://dx.doi.org/10.17977/UM014v10i12017p026

Cresswell, J. W. (2014). Researh Design: Qualitative, Quantitative, and Mixed Method Approaches. Thousand Oaks, CA: Sage. Dimyati \& Mudjiono. (2006). Belajar dan Pembelajaran. Jakarta: Rineka Cipta.

Etika, N., \& Hasibuan, W. F. (2016). Deskripsi Masalah Mahasiswa Yang Sedang Menyelesaikan Skripsi. Jurnal KOPASTA, $3(1), 40-45$.

Fahrurrozie., Kiswanto., \& Asrori. (2018). Analisis Kendala dan Percepatan Penyelesaian Studi Mahasiswa Jurusan Akutansi. Jurnal Pendidikan dan Sosial, 28(1), 66-85.

Giyono. (2010). Bimbingan dan Konseling di Sekolah (Diktat). Bandar Lampung: Universitas Lampung.

Hamka, L., \& Hartono. (2012). Prestasi Belajar Mahasiswa Penerima Beasiswa Bidik Misi FMIPA UNM Tahun Akademik 2010-2011. Jurnal Sainsmat, 1(1), 52-60.

Ihsan, H., \& Zaki, A. (2015). Analisa Faktor-faktor Yang Menghambat Penyelesaian Studi Mahasiswa FMIPA UNM. Jurnal Scientific Pinisi, 1(1), 25-33.

Kharismayanti, S. I. (2017). Pola Penggunaan Dana dan Gaya Hidup Mahasiswa Penerima Beasiswa Bidikmisi di Fakultas Ekonomi Universitas Negeri Yogyakarta. Jurnal Pendidikan dan Ekonomi, 6(4), 400-410.

Purwanto, M. N. (2002). Psikologi Pendidikan. Bandung: Remaja Rosda Karya.

Raharjo. (2014). Problem dan Solusi Studi Mahasiswa Semester Tua. Nadwa: Jurnal Pendidikan Islam, 8(2), 313-336.

Rahmiati. (2014). Analisis Kendala Internal Mahasiswa Dalam Menulis Karya Ilmiah. Jurnal Alidaulah, 4(2), $327-343$.

Rismen, S. (2015). Analisis Kesulitan Mahasiswa Dalam Penyelesaian Skripsi di Prodi Pendidikan Matematika STKIP PGRI. LEMMA, 1(2), 57-62.

Rohmawan, E. P. (2018). Prediksi Kelulusan Mahasiswa Tepat Waktu Menggunakan Metode Decision Tree dan Artificial Neural Network. Jurnal Ilmiah Matrik, 20(1), 21-30.

Samekto, D., Syafrudie, H. A., \& Sutrisno (2014). Kecenderungan Lama Studi dan Prestasi Belajar Mahasiswa Jalur Reguler dan Non-Reguler Program Studi Pendidikan Teknik Bangunan. Jurnal Teknologi dan Kejuruan, 37(2), $153-166$.

Siang, J. J. (2009). Cara Cepat Menyusun Skripsi. Yogyakarta: Penerbit Andi.

Sudjana, N \& Rivai A. (2001). Media Pengajaran. Bandung: Sinar Baru.

Sugiarto, E. (2002). Psikolosi Pelayanan Dalam Industri Jasa. Jakarta: Gramedia.

Saparwadi, L., \& Aini, Q. (2016). Identifikasi Masalah Pembelajaran Mahasiswa Pendidikan Matematika pada Matakuliah Program Linear: Studi Kasus pada Program Studi Pendidikan Matematika. Jurnal Tatsqif: Jurnal Pemikiran dan Penelitian Pendidikan, 14(1), 33-48.

Sumartini, D. (2018). Metode Guided Discovery Learning terhadap Tingkat Berpikir Kritis Siswa Dilihat dari Motivasi Belajar. Indonesian Journal of Economics Education, 1(1), 1-8.

Takriyuddin, H., Mukmin, Z., \& Yunus, M. (2016). Pengaruh Beasiswa Bidikmasi terhadap Prestasi Belajar Mahasiswa Program Studi Pendidikan Pancasila dan Kewarganegaraan Fakultas Keguruan dan Ilmu Pendidikan Universitas Syiah Kuala. Jurnal Ilmiah Mahasiswa Pendidikan Kewarganegaraan Unsyah, 1(1), 49-60.

Widarto. (2017). Faktor Penghambat Studi Mahasiswa yang Tidak Lulus Tepat Waktu di Jurusan Pendidikan Teknik Mesin FT UNY. Jurnal Dinamika Vokasional Teknik Mesin, 2(2), 127-138.

Winkel, W. S. (2004). Psikologi Pegajaran. Yogyakarta: Media Abadi.

Yin, R. K. (2002). Studi Kasus Desain dan Metode. Jakarta: Raja Grasindo Persada. 